\title{
AN INVESTIGATION INTO THE READING PATTERNS OF KHANDWA DISTRICT STUDENTS
}

\author{
Sunita Pamnani ${ }^{1} \rrbracket$, C.S Shrivastava ${ }^{2}$, Hemlata Nagar ${ }^{3}$ (D) \\ Department of Mathematics (Computer Science), Faculty of Science, Tanta University, Egypt. \\ Faculty of Computers and Information, Menofia University, Egypt.
}

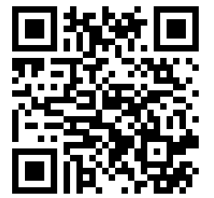

\section{ABSTRACT}

Received 01 June 2021

Accepted 15 June 2021

Published 06 September 2021

\section{CorrespondingAuthor}

Sunita Pamnani, sunitapamnani@yahoo.com

DOI 10.29121/IJOEST.v5.i5.2021.202

Funding: This research received no specific grant from any funding agency in the public, commercial, or not-for-profit sectors.

Copyright: (C) 2021 The Author(s). This is an open access article distributed under the terms of the Creative Commons Attribution License, which permits unrestricted use, distribution, and reproduction in any medium, provided the original author and source are credited.

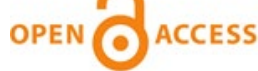

The aim of the research was to evaluate students' reading patterns and how they affected their academic success. The research was carried out in the Khandwa District of Nimar's Eastern Region. The data was gathered using a questionnaire. The obtained data was quantitatively studied using the Statistical Package for Social Science (SPSS).The findings were presented in the form of graphs and charts. 100 of the 150 questionnaires circulated were filled and returned, accounting for 95.0 percent of the total. The results revealed that while the majority of respondents recognize the value of reading, 81.9 percent of respondents have not read a book or a piece of fiction in the last two semesters, and 62.0 percent of respondents still read to pass an exam.The study found that reading habits have an impact on academic success and that there is a connection between reading habits and academic achievement. The study suggested, among other things, that lecturers avoid handing out handouts to students and instead allow them to use the library for studying, and that the new method of grading students be reconsidered in terms of grading formulae.

Keywords: Reading Habbits, Use of Library Material, Knowledge Management

\section{INTRODUCTION}

Reading is an excellent activity to cultivate throughout one's life. Good books will educate, inform, and guide you in the right way. There is nothing like a decent book to keep you company. Reading exercise is important because it benefits your physical health. You enter a whole new universe until you begin reading. When you develop a passion for reading practice, you will get addicted to it. Reading practice improves grammar and linguistic skills.

Readers learn healthy reading habits in addition to practicing reading techniques. These habits, including eating every day, can come easily. Students would be more willing to take on these tasks if they appreciate that it is necessary to adopt this list. Reading is also a good way to unwind and destress. It is important to stretch muscles by reading a decent book for at least a few minutes per day in order to maintain proper functioning.

\section{Academic Institutions' Reading Preferences}

Reading is a process-oriented skill that can be practiced. Until understanding, it includes the mechanics of the and the combination of other organs. When a procedure is repeated repeatedly, it becomes a routine. Reading is a good routine to get into because it promotes professional growth 
and social change in general.

An person organized his reading in a way that suited his preferences in Journal of Education. Shen (2006) divides reading into three categories: how much, how long, and what a student reads at any given time.

Many scholars, including Ogbodo (2002), Bhan \& Gupta (2010), and Singh (2011), have studied reading and how it influences students' academic success. The majority of these works, though, are focused on the international community. Few studies in Ghana, such as Ward (1997) and Agbezree (2001), were limited to primary and secondary education. In light of this, it has become important to undertake a similar analysis in Ghana to investigate the impact of reading patterns on students' academic success at the tertiary level of education, with a focus on Koforidua Polytechnic.

Reading is a talent that requires you to do something. Before understanding, it includes the mechanics of the cortex and a combination of other organs. When you do something on a regular basis, it becomes a habit. Reading is beneficial to one's professional growth as well as social change in general. Reading habit describes the behavior that reflects a preference for certain styles of reading and preferences of reading (Chettri and Rout (2013)). This reading is tailored to his preferences. Shen (2006) divides reading into three categories: how much, how long, and what a student reads at any given time.

\section{OBJECTIVES OF THE STUDY}

The study's overall goal is to determine how students' reading patterns influence their academic success.

The below are the specific goals:

1) To investigate students' reading patterns (styles).

2) To determine the impact of students' reading patterns on their academic success.

3) To look at what students read while they go to the library.

4) To figure out why students want to learn.

\section{LITERATURE REVIEW}

According to Guthrie et al. (2007), "reading" is the process of extracting information from printed or written texts, which is the foundation for learning and one of the most essential skills in daily life..

(Issa et al 2012) go on to say that reading is commonly synonymous with books and only written words can fully describe the process of reading. It means that a person can use reading to create or repair objects, enjoy stories, learn about other people's views, and grow their own ideas or beliefs. As a result, reading gives us access to all types of knowledge that we need to survive and expand on a daily basis.

Reading for pleasure or relaxing is a popular pastime among the educated elite. People who work for a living spend their days in offices attempting to fix issues related to their careers. When they get home from college, they usually want to read something fresh and interesting, so they read novels, journals, and other written materials. Instead of reading textbooks all of the time, students should be allowed to read magazines. Students who read magazines at regular intervals learn to relax, calm their brains, and prevent emotional exhaustion, as well as maintain a disciplined school life. 


\section{METHODOLOGY}

Data was collected using a survey method using a questionnaire. With the help of qualified researchers, copies of the questionnaire were distributed to Khandwa students during lecture hours. The district covers $6206 \mathrm{~km} 2$ and has a population of $1,310,061$ people (2011 census). Khandwa District is part of the Nimar province, which includes Kherkhali, the Narmada River's lower valley. The Narmada River forms part of the district's northern border, while the Satpura Range forms the district's southern boundary. Burhanpur District is located in the Tapti River's basin to the south. The Satpuras Pass, which connects Khandwa and Burhanpur, is one of the major roads linking the north and south.

The questionnaire was pilot-tested on a comparable but smaller study group from a neighboring college during the second year of the 2020/2021 academic year to enhance the testing instrument's reliability and validity. The data was first registered on data sheets and then manually entered into the machine. They are calculated using the Excel program. The use of percentages is used to interpret the overall results. One hundred copies of the questionnaire were filled and returned out of a total of 152 copies released, reflecting a response rate of 95.0 percent.

\begin{tabular}{|ccc|}
\hline Table 1 Times Spent on Reading & & \\
\hline Reading Time & No. of. Respondents & Percentage \\
\hline Less than 1 hour & 65 & $65 \%$ \\
\hline 1-3 hours & 25 & $25 \%$ \\
\hline 4-6 hours & 10 & $10 \%$ \\
\hline Total & $\mathbf{1 0 0}$ & $\mathbf{1 0 0} \%$ \\
\hline
\end{tabular}

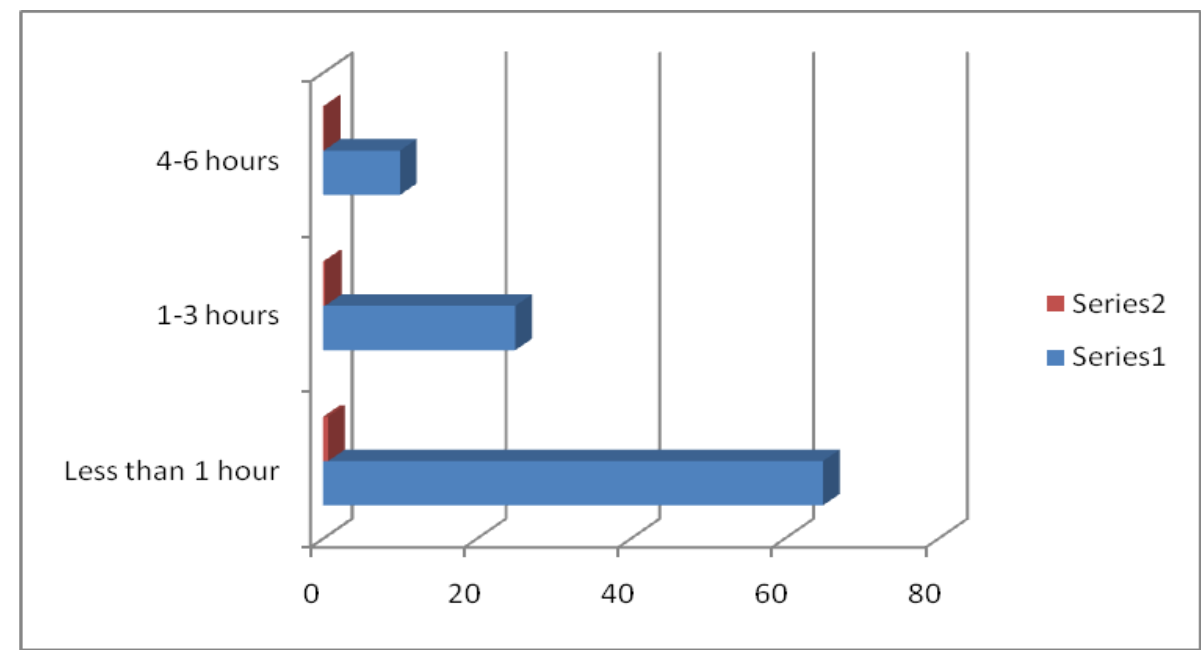

Figure 1 
Table 1 shows how much time was spent reading books and other reading content. 65 percent of respondents said they read for less than an hour, 25 percent said they read for 1-3 hours, and ten percent said they read for 3-6 hours.

\begin{tabular}{|lcc|}
\hline Table 2 Purpose of reading books & & Percentage \\
\hline Purpose of reading books & No. Of Students & $63 \%$ \\
\hline Self expression & 63 & $15 \%$ \\
\hline Learn new things & 15 & $22 \%$ \\
\hline Imagination of things & 22 & 100 \\
\hline Total & 100 & \\
\hline
\end{tabular}

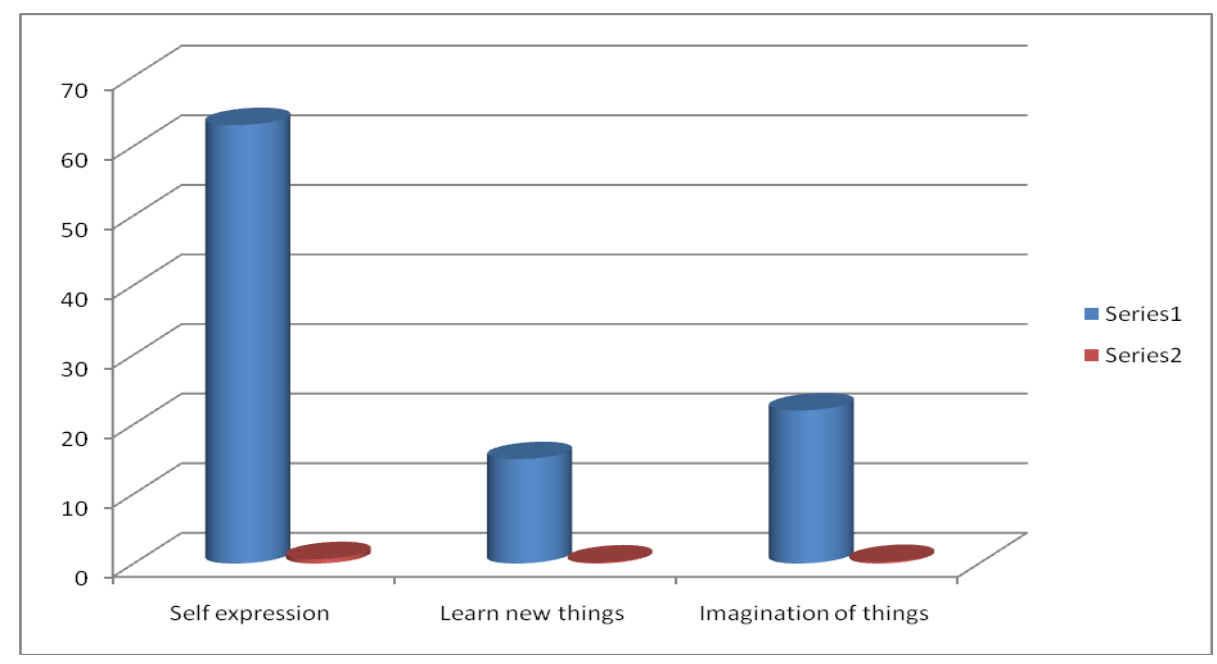

Figure 2

According to Figure 2, 62.1 percent of total respondents said reading a book or fiction helps them express themselves better, 14.9 percent said it helps them discover new ideas, 10.1 percent said it helps them imagine new things, 23 percent said it complements their research, and 4.0 percent said it prevents them from getting bored. The majority of the respondents seemed to believe that reading a book or fiction allows them to articulate themselves effectively.

\begin{tabular}{lllll}
\hline Table 3 & & & & \\
\hline Types of material & Daily & Weekly & Once a month & Once a year \\
\hline Bestsellers & 41.0 & 30.5 & 22 & 6.5 \\
\hline Motivational books & 55.5 & 26.0 & 3.0 & 3.0 \\
\hline Novels & 53.5 & 14.5 & 3.5 & 6.5 \\
\hline Informational books & $45.0 \%$ & 29.5 & 20.0 & 6.0 \\
\hline Special books & $65.0 \%$ & $25 \%$ & $9 \%$ & $0.5 \%$ \\
\hline Textbooks from various fields & 62 & 28.5 & 8.5 & 1.0
\end{tabular}




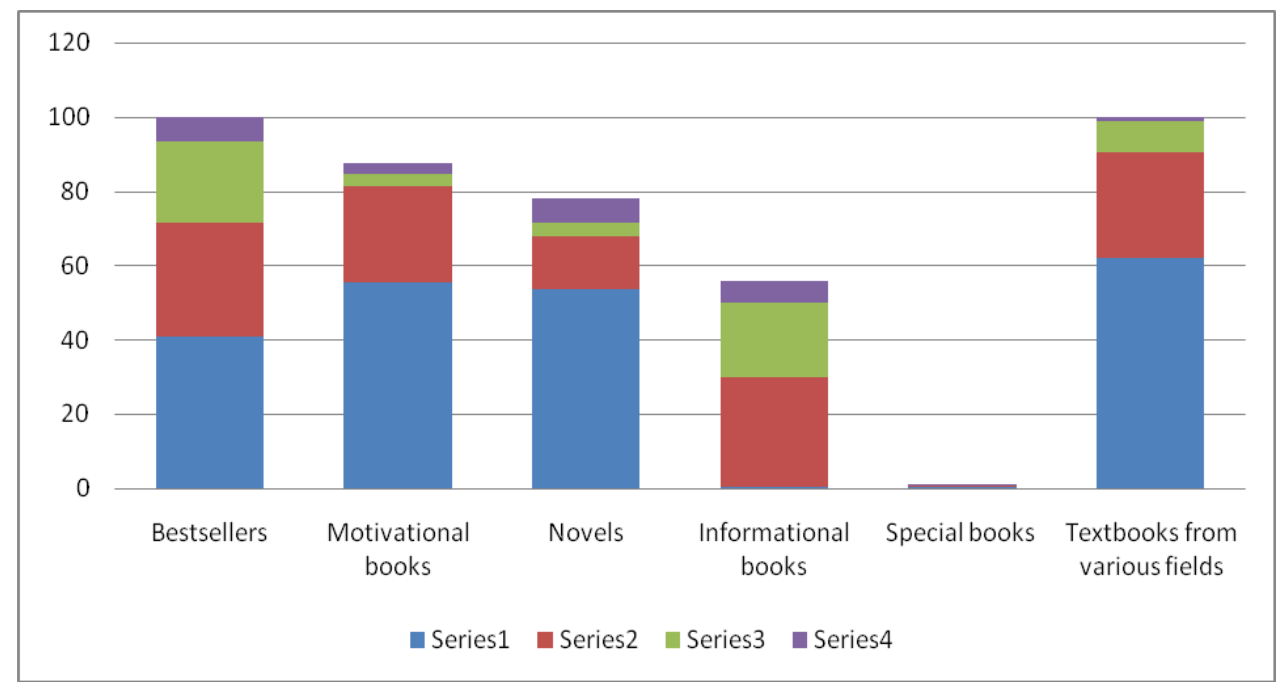

Figure 3

Table 3 depicted the reading patterns of Khandwa district college students. According to the index, 62 percent of students claim to enjoy reading textbooks from various fields on a regular basis, 28.5 percent claim to enjoy reading textbooks from various fields on weekends, 8.5 percent claim to read textbooks from various fields once a month, and 1.0 percent claim to read textbooks from various fields once a year.In addition, 41.0 percent of respondents said they read bestsellers from novels and other prose works on a regular basis. 30.5 percent of college students said they enjoy reading bestsellers from novels and other prose works on weekends; 22.0 percent of college students said they enjoy reading bestsellers from novels and other prose works once a month; and 6.5 percent of college students said they enjoy reading bestsellers from novels and other works once a year.

Similarly, 55.5 percent of College students read motivational books on a regular basis, 26.0 percent read motivational books once a week, and 3.0 percent read motivational books once a year. In addition, 53.5 percent of College students enjoy reading novels on weekends, 14.5 percent enjoy reading novels once a month, and 3.5 percent enjoy reading novels once a year, according to the index. In addition, 45.0 percent of college students said they enjoy reading information books on a regular basis, and 29.0 percent said they enjoy reading information books on weekends. Once a month, 20.0 percent enjoy reading biographies, and once a year, 6.0 percent enjoy reading knowledge books. Table 3 also revealed that 65.5 percent of college students enjoy reading books in their fields of study on a regular basis, 25.0 percent enjoy reading books in their fields of study on a weekly basis, 9.0 percent enjoy reading books in their fields of study once a month, and 0.5 percent enjoy reading books in their fields of study once a year.

\section{CONCLUSION}

Students should be taught to create a program that includes a variety of learning experiences. Reading has long been a hobby with great personalities throughout history. This aided in the preservation, posterity, and transmission of information through centuries. As a result, one's reading habit has an effect on one's 
personal growth as well as social advancement in general. Reading on a regular and systematic basis sharpens the mind, refines the passions, elevates flavors, and gives us a new perspective on life. To put it another way, it prepares an individual to participate effectively in social, religious, educational, and political life. Reading stimulates a person's creativity by giving them new eyesight and new wisdom.

\section{REFERENCES}

Akabuike, I. G. and Asika, I.E. (2012) Reading habits of undergraduates and their academic performances: Issues and Perspectives. 6(2). Pp 246-257. Retrieved from https://doi.org/10.4314/afrrev.v6i2.22

Akarsu, 0. and Darryemez, T. (2014). The reading habits of University students studying English language and literature in the digital age. Journal of Language and Linguistic Studies 10(2), pp 85- 99. Retrieved from https://dergipark.org.tr/en/pub/jlls/issue/9939/122964

Alamdar, H., Bakhtar, M., SheikhFathollahi, M., \& Rezaeian, M. (2017). A survey on the study habits in students of Rafsanjan University of medical sciences in 2015. Journal of Rafsanjan University of Medical Sciences, 16(2), 155-168.

Aydin, G., \& Ayranci, B. B. (2018). Reading Preferences of Middle School Students. World Journal of Education, 8(2), 127-139. Retrieved from https://doi.org/10.5430/wje.v8n2p127

Begad Amritlal (2018) Narmada ki Atmakatha Bhopal M.P. hindi granth acedamy page 129-132

Chettri, K. and Rout, S.K. (2013). Reading Habits: An overview. Journal of Humanities and Social Science (I05R-JH55) (14) 6. pp 13-17. Retrieved from https://doi.org/10.9790/0837-01461317

Dipika Md.Mehedi (2013). Newspaper reading habits of private University students: A case study on world University of Bangladesh. IOSR Journal of Business and Management. 12(1), pp 87-91. Retrieved from www.iosrjournals.org on April 16, 2016. Retrieved from https://doi.org/10.9790/487X-1218791

Green, P (2002). Teachers intervention in children's reading. Journal of Child Hood Education, 46(3). pp 147-149. Loan, F.A. (2012).

Guthrie J.T. Benneth, L \& Mc Gough, K (2007), Concept-oriented Reading Instruction: An Integrated Curriculum to Develop Motivations and Strategies for Reading Retrieved from http://curry.virginia.edu/go/clic/nrrc/corri_rlo.html Retrieved on November, 282013.

Molotja, T. W., \& Themane, M. (2018). Enhancing learners' reading habits through reading bags at secondary schools. Reading \& Writing, 9(1), 1-9. Retrieved from https://doi.org/10.4102/rw.v9i1.185

Reading habits of rural ( 2016) and urban College students in the 21st century. Journal of Library Philosophy and Practice: Libraries at University of Nebraska, Lincoln. ISSN 1522-0222. pp 1-11 Retrieved from http://unlib.un \.edu \lpp $\backslash$ on January 6.

Gilavand, A. (2018). Investigating the effect of using mobile educational application of study habits on improving students' awareness concerning proper study habits. J Res Med Dent Sci, 6, 273-7. Retrieved from https://www.researchgate.net/profile/Abdolreza-

Gilavand/publication/331071989_Investigating_the_effect_of_using_Mobil 
e_Educational_Application_of_Study_Habits_on_Improving_Students'_Awar eness_Concerning_Proper_Study_Habits/links/5c64391b45851582c3e6cf9 8/Investigating-the-effect-of-using-Mobile-Educational-Application-ofStudy-Habits-on-Improving-Students-Awareness-Concerning-ProperStudy-Habits.pdf

Kavi, R. K., Tackie, S. N., \& Bugyei, K. A. (2015). Reading for pleasure among junior high school students: case study of the Saint Andrews Anglican Complex Junior High School, Sekondi. Retrieved from http://ugspace.ug.edu.gh/handle/123456789/27100

Owusu-Acheaw, M., \& Larson, A. G. (2014). Reading habits among students and its effect on academic performance: A study of students of Koforidua Polytechnic. Library philosophy and practice, 0_1. Retrieved from https://d1wqtxts1xzle7.cloudfront.net/52948426/fulltext-with-coverpage-

v2.pdf?Expires $=1630924229 \&$ Signature $=J c w F 3$ dupRreZGCRNUwqt5ZDVC wopctCaRkD4Kgu7R030uj6J5trlsFs f2Mf6hqhtHZWxky1xsCeJXE4AtSg1f 1qZu8jhKQhlg9TmKNU1BDKmKiIrGZbj0QM6XBMloPIBLXD8EUMHmiR30 niSrW8JqBX-pzS q3Zulr4qc9ebI9VoElDv6c1hyxTNI-

FALMg8AUgVH8qbUQbObQ8SLoQw2fYNQ0tjZLKwXTkjkso5wk2DWOgj4v u8Xkltq2WqpvHjVeDg8GYUKY5-

X5E9Q2rhjS069tBJFfJDjNoQMbuUy6NaeMDSdf0KOMAJRumi9CjPsdm4Rg6 cDichtzuU6QjwQ_\&Key-Pair-Id=APKAJLOHF5GGSLRBV4ZA

Ogunrombi, S. A., \& Adio, G. (1995). Factors affecting the reading habits of secondary school students. Library Review, 44(4), 50-57 Retrieved from https://doi.org/10.1108/00242539510089750

Siahi, E. A., \& Maiyo, J. K. (2015). Study of the Relationship between Study Habits and Academic Achievement of Students: A Case of Spicer Higher Secondary School, India. International Journal of Educational Administration and Policy Studies, 7(7), 134-141. Retrieved from https://doi.org/10.5897/IJEAPS2015.0404

Sharma, D. (2018). Construction and validation of the study habits scale for the secondary school students. International Journal of Research in Social Sciences, $\quad 8(1)$. Retrieved from https://www.indianjournals.com/ijor.aspx?target=ijor:ijrss\&volume=8\&is sue $=1 \&$ article $=069$ 